https://doi.org/10.35339/msz.2019.83.02.02

УДК 611:57.086:517:530.191

\author{
Н.І. Мар'єнко, О.Ю. Степаненко
}

Харківський національний медичний університет

\title{
ДВА СПОСОБИ ФРАКТАЛЬНОГО АНАЛІЗУ ЯК МОРФОМЕТРИЧНОГО МЕТОДУ В АНАТОМІї: СПОСІБ ПІДРАХУНКУ КВАДРАТІВ VS СПОСІБ ДИЛАТАЦІЇ ПІКСЕЛІВ
}

\begin{abstract}
Проведено порівняльний аналіз двох способів фрактального аналізу як методу морфометрії - підрахунку квадратів і дилатації пікселів. Для розробки методик фрактального аналізу використано білу речовину мозочка людини. Порівняно дві авторські модифікації методів фрактального аналізу. За результатами підрахунку фрактального індексу двома різними методами на одному зображенні встановлено, що значення фрактального індексу, обчислені методами підрахунку квадратів і дилатації пікселів, майже не розрізняються. Обидва методи дають порівнянні результати і можуть бути використані для фрактального аналізу в морфометрії з однаково високою точністю. Вибір методу залежить від особливостей зображення й досліджуваної структури. У випадках, якщо зображення легко автоматично розділити на фон і основну структуру, методом вибору $є$ метод дилатації пікселів. Для більш складних структур і зображень може бути застосований рутинний метод підрахунку квадратів.

Ключові слова: морфометрія, фрактальний аналіз, фрактальний індекс, підрахунок квадратів, дилатація пікселів.
\end{abstract}

\section{Ветуп}

Фрактальний аналіз є відносно новим перспективним морфометричним методом у морфології. Він дозволяє кількісно оцінювати окремі морфологічні характеристики біологічних структур, які складно об'єктивно оцінити традиційними методами морфометрії [1]. Фракmалом є структура або математична множина, для якої характерні масштабна інваріантність і самоповторюваність: частини цієї структури на різних рівнях організації повторюють будову структури в цілому. Будова фрактальних структур може бути описана за допомогою математичних формул та алгоритмів [2, 3]. Ті природні структури, будова яких має властивості фракталів, але не має чіткої математичної закономірності їхньої організації, нази- вають квазифрактальними. До таких структур належать судинна мережа органів, протоки залоз, бронхіальне дерево, дендритне дерево нейронів, біла речовина мозочка та ін. [4]. Для того, щоб визначити складність просторової організації цих структур (як правило, ступінь розгалуженості), і використовують фрактальний аналіз. Величина, що визначають при цьому, - фрактальний індекс, який у випадку морфометрії двовимірного об'єкта варіює від 1 до 2 [4].

Для визначення фрактального індексу використовують різні способи, серед яких найчастіше - спосіб підрахунку квадратів (box counting) [5-7], трохи рідше - спосіб дилатації пікселів (pixel dilating) [8]. Існує багато варіантів і модифікацій цих способів, розроб-

(C) Н.I. Мар'єнко, О.Ю. Степаненко, 2019 
лених залежно від досліджуваних об'єктів [913]. Для того, щоб визначити рівноцінність чи нерівноцінність двох способів фрактального аналізу, їхні переваги та недоліки, ми провели порівняльне дослідження на однаковому матеріалі.

Мета даного дослідження - порівняльний аналіз двох способів фрактального аналізу - підрахунку квадратів та дилатації пікселів.

\section{Матеріал і методи}

Як об'єкт дослідження використано arbor vitae - білу речовину черв'яка мозочка людини, що є типовою фрактальною анатомічною структурою [5-7, 12, 13]. Досліджували цифрові зображення серединного сагітального розтину черв'яка мозочка людини, отримані з незабарвлених препаратів (використаний секційний матеріал; мозочок фіксований у $10 \%$ формаліні протягом місяця), puc. $1, a$.

Обробку цифрових зображень і морфометричний етап фрактального аналізу здійснювали за допомогою програми Adobe Photoshop CS5. Для проведення фрактального аналізу незалежно від методики калібрували цифрові зображення та «вирізали» із них ділянку квадратної форми, що містить досліджувану структуру. Після необхідної підготовки зображення проводили морфометричний етап дослідження, який власне й розрізняється за різних способів.
За способу підрахунку квадратів використовують морфометричні сітки. На квадрат із зображенням, що містить досліджувану структуру, накладають сітку, що ділить сторону квадрата навпіл. Потім послідовно накладають сітки, що ділять сторону квадрата на 4, 8, 16 та 32 частини. Таким чином, із кожним кроком удвічі зменшують розмір сторони квадратів морфометричної сітки. На кожному етапі підраховують кількість квадратів $(\mathrm{N})$, що містять фрагменти досліджуваної структури (рис. 1, б-e).

Для морфометрії способом дилатаиїі пікселів установлюють роздільну здатність зображення таким чином, щоб розмір квадрата цифрового зображення становив $64 \times 64$ пікселі (puc. 2, a). Потім поетапно збільшують розміри пікселя вчетверо, зменшуючи роздільну здатність зображення вдвічі, тобто здійснюють дилатацію пікселів (рuс. 2, б-e). Розміри зображення в пікселях послідовно зменшуються з $64 \times 64$ до $32 \times 32,16 \times 16,8 \times 8,4 \times 4$ та $2 \times 2$ пікселі. На кожному етапі підраховують кількість пікселів (N), що містять фрагменти досліджуваної структури.

Дані підрахунків заносять у таблицю (табл. 1, 2).

В таблицю також вносять показник bох size, що характеризує відношення сторони
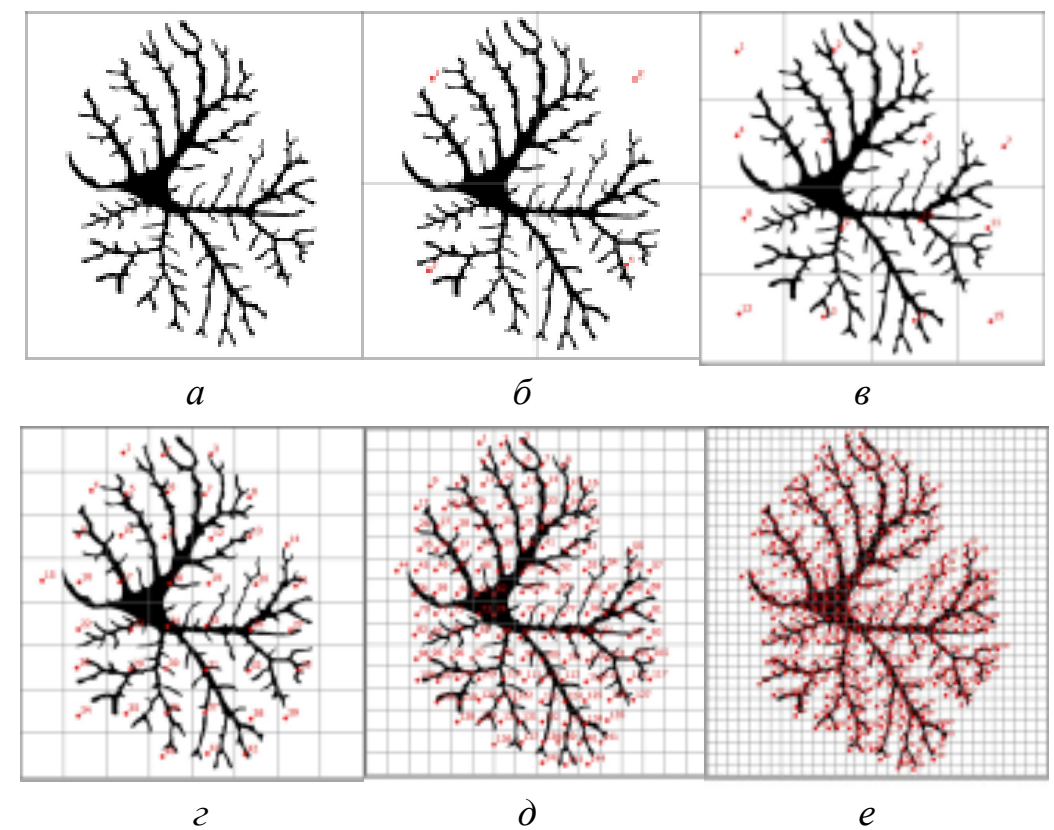

Рис. 1. Етапи морфометричного дослідження при проведенні фрактального аналізу білої речовини мозочка способом підрахунку квадратів 


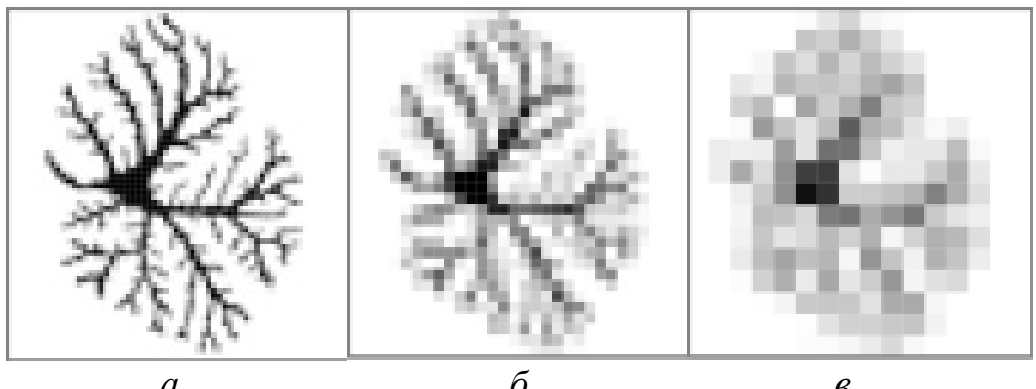

$a$

$\sigma$

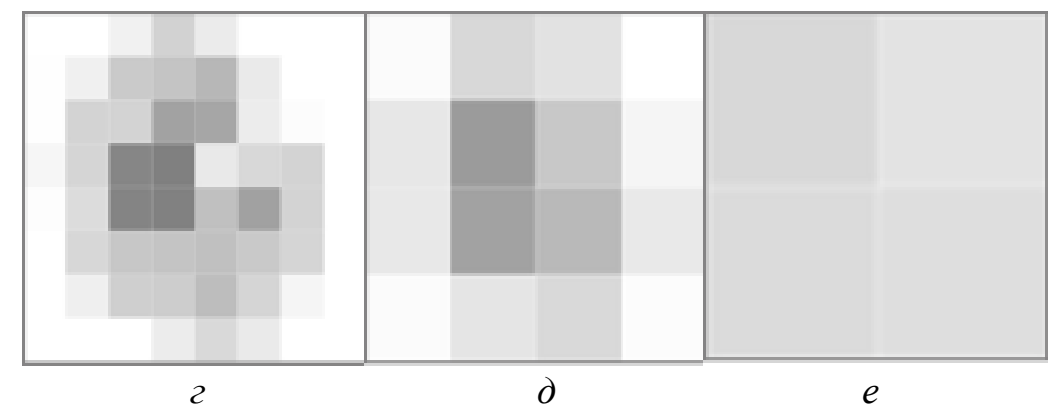

Рис. 2. Етапи фрактального аналізу білої речовини мозочка способом дилатації пікселів

квадрата морфометричної сітки (за першого способу) або пікселя (за другого) до розміру сторони квадрата зображення об'єкта.

Наступний етап, а саме розрахунок фрактального індексу, за різних способів суттєво не розрізняється. Розраховують натуральний логарифм числа заповнених квадратів або пікселів $(\ln (\mathrm{N}))$ та натуральний логарифм числа, зворотного показнику box size $(\ln (1 /$ box size)), табл. 1, 2.
За даними табл. 1 або 2 (залежно від способу) розраховують рівняння лінійної регресії залежності $\ln (\mathrm{P})$ від $\ln (1 /$ box size $)($ рис. 3,4$)$ i встановлюють фрактальний індекс, який дорівнює коефіцієнту нахилу прямої регресії відносно осі абсцис.

\section{Результати та їх обговорення}

За результатами підрахунку фрактального індексу способом підрахунку квадратів отримано рівняння лінійної регресії $y=1,6116 x$

Табличя 1. Етапи підрахунку фрактального індексу мозочка за допомогою підрахунку квадратів

\begin{tabular}{|c|c|c|c|c|}
\hline $\begin{array}{c}\text { Етап } \\
\text { дослідження }\end{array}$ & Box size & Кількість заповнених квадратів (N) & In (1/box size) & $\ln (\mathrm{N})$ \\
\hline 1-й & $1 / 2$ & 4 & 0,69 & 1,39 \\
\hline 2-й & $1 / 4$ & 15 & 1,39 & 2,71 \\
\hline 3-й & $1 / 8$ & 42 & 2,08 & 3,74 \\
\hline 4-й & $1 / 16$ & 144 & 2,77 & 4,97 \\
\hline 5-й & $1 / 32$ & 412 & 3,47 & 6,02 \\
\hline
\end{tabular}

Таблиия 2. Етапи підрахунку фрактального індексу мозочка за допомогою дилатачії пікселів

\begin{tabular}{|c|c|c|c|c|}
\hline $\begin{array}{c}\text { Етап } \\
\text { дослідження }\end{array}$ & Box size & Кількість заповнених пікселів (Р) & In (1/box size) & $\ln (P)$ \\
\hline $1-\breve{n}$ & $1 / 64$ & 1276 & 4,16 & 7,15 \\
\hline $2-\check{n}$ & $1 / 32$ & 501 & 3,47 & 6,22 \\
\hline $3-\breve{n}$ & $1 / 16$ & 152 & 2,77 & 5,02 \\
\hline $4-\breve{n}$ & $1 / 8$ & 45 & 2,08 & 3,81 \\
\hline $5-\check{n}$ & $1 / 4$ & 15 & 1,39 & 2,71 \\
\hline $6-\check{и}$ & $1 / 2$ & 4 & 0,69 & 1,39 \\
\hline
\end{tabular}




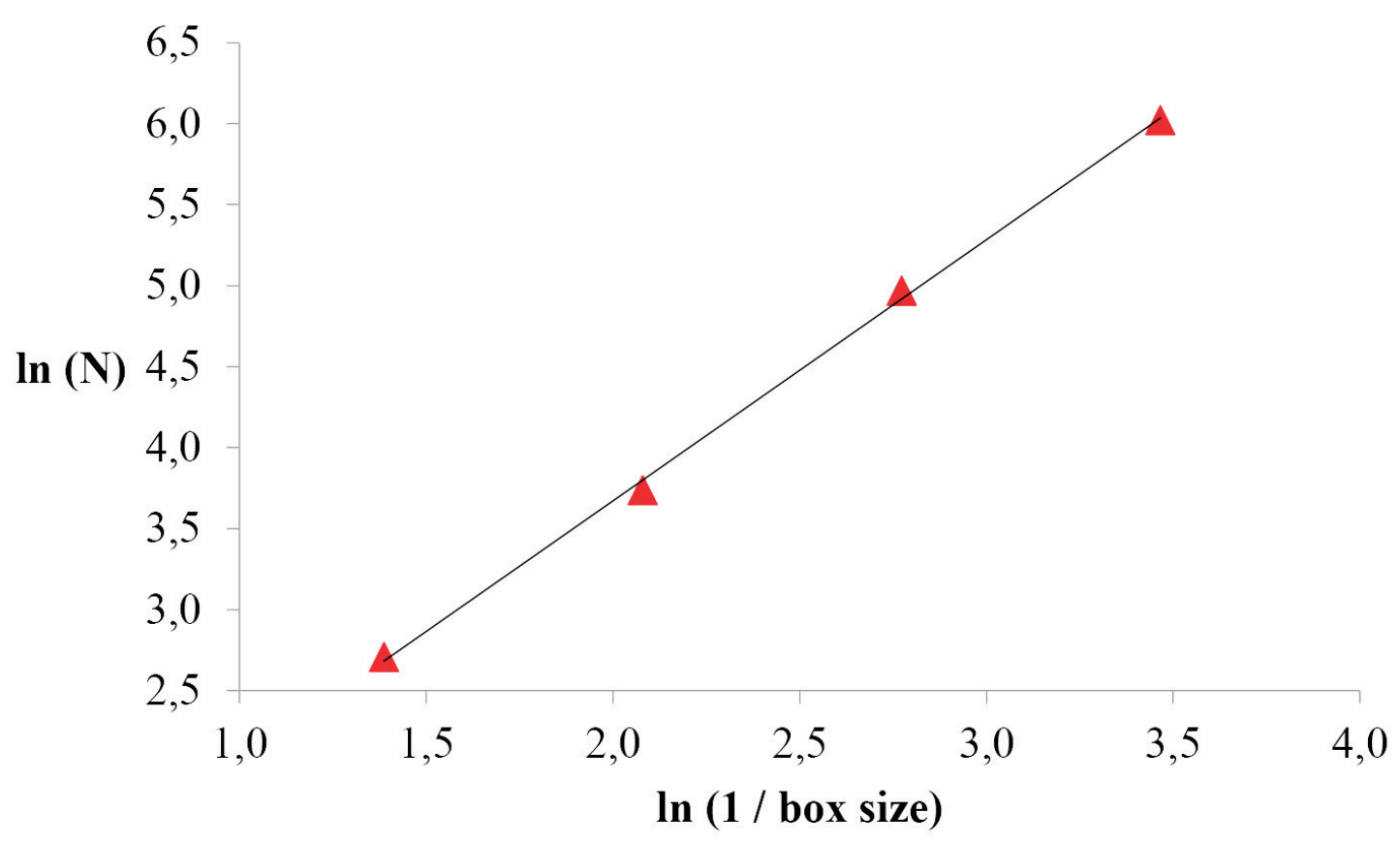

Рис. 3. Підрахунок фрактального індексу білої речовини мозочка способом підрахунку квадратів

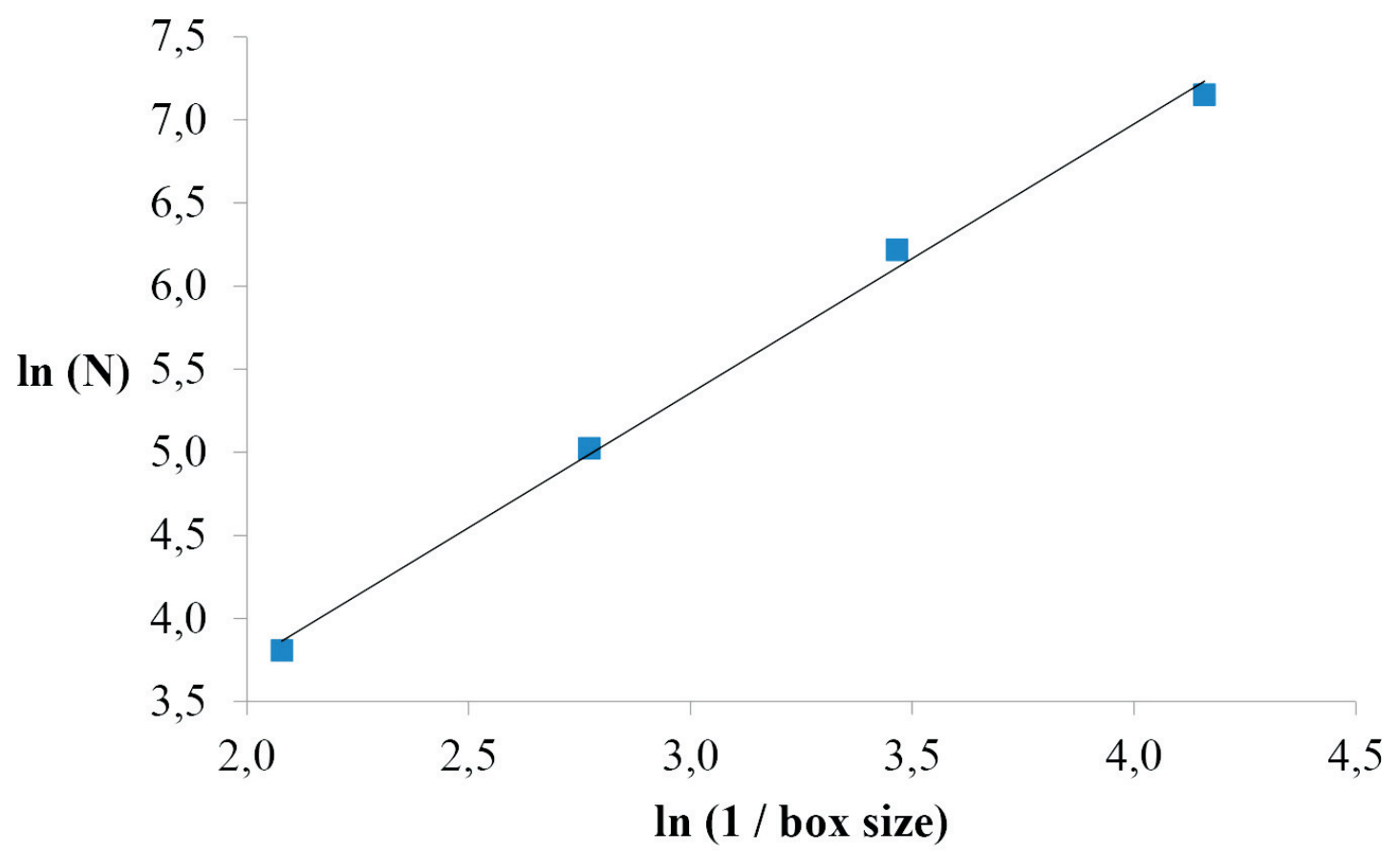

Рис. 4. Підрахунок фрактального індексу білої речовини мозочка способом дилатації пікселів

$+0,4493$, отже, фрактальний індекс становить 1,6116; способом дилатації пікселів $-y=$ $1,6197 x+0,4974$, тобто фрактальний індекс становить 1,6197 . Таким чином, значення фрактального індексу однісї структури, обчислені різними способами, майже не розрізня- ються, а різниця цих значень становить $0,5 \%$ від їхнього середнього значення. 3 метою оцінювання статистичної значущості відмінності отриманих значень фрактального індексу коефіцієнт нахилу й коефіцієнт зсуву рівняння лінійної регресії були порівняні за допомогою 
критерію Ст'юдента (Т-тест). Установлено, що ці коефіцієнти значущо не розрізняються ( $>00,05)$. Рівняння регресії в цілому були порівняні між собою за допомогою критерію Фішера (F-тест): вони також значущо не розрізняються $(\mathrm{p}>0,05)$, що підтверджує нульову гіпотезу про співпадіння ліній рівнянь лінійної регресії. Отже, обидва способи принципово схожі, дають співставні результати та можуть бути використані для фрактального аналізу в морфометрії з однаково високою точністю.

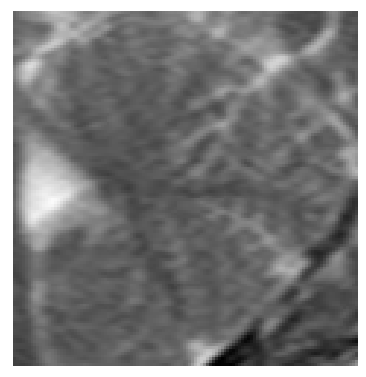

$a$

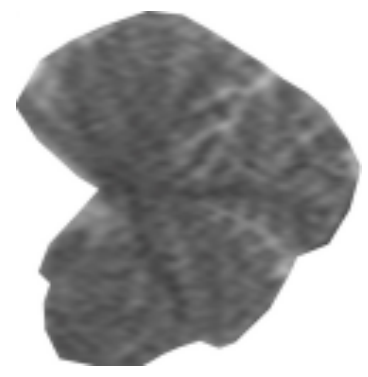

6 рожні») пікселі, що не містять цієї структури, - у другий (рис. 5).

Однак цей спосіб контрастування не придатний для конвертації цифрових зображень нативних або фіксованих незабарвлених анатомічних макропрепаратів, гістологічних мікропрепаратів із невеликою контрастністю та у випадках, коли досліджувана структура забарвлена нерівномірно, має декілька кольорів чи кольори, що повторюються у фонових структурах або iї яскравість близька до яскравості фону. У цих випадках можна прово-

Рис. 5. Автоматизоване контрастування речовини магнітно-резонансної томограми мозочка за допомогою програми Adobe Photoshop

Кожний спосіб має особливості виконання й переваги застосування залежно від досліджуваної структури.

Для обох способів фрактального аналізу необхідною умовою дослідження є чітке відмежування досліджуваної структури від оточуючих тканин та структур. Однак обидва способи потребують різної підготовки зображення до проведення дослідження.

Для способу дилатаиії пікселів необхідною умовою дослідження є попереднє контрастування зображення. Для цього зображення переводять у бінарний режим: воно має містити пікселі лише двох кольорів - чорні (зі значенням яскравості 0) та білі (зі значенням яскравості 255). Для томограм, рентгенограм та досить контрастних зображень гістологічних мікропрепаратів, де досліджувана структура забарвлена рівномірно, може бути використане автоматизоване контрастування за допомогою інструмента «Поріг» програми Adobe Photoshop. Цей інструмент забарвлює всі пікселі, світліші за задане порогове значення, у білий колір, темніші - у чорний. Таким чином, усі пікселі, що відповідають досліджуваній структурі, стають забарвленими в один колір (чорний або білий), фонові («по- дити ручне контрастування: виділення структур і забарвлення їх у певний колір (чорний або білий), а фонових пікселів - у протилежний. Ручне контрастування білої речовини мозочка на незабарвленому препараті продемонстровано на рис. 6.

Контрастування зображення $\epsilon$ обов'язковим етапом за способу дилатації пікселів, але необов'язковим - за способу підрахунку квадратів (якщо межі досліджуваної структури визначаються чітко), оскільки наявність чи відсутність певних структур на досліджуваній ділянці зображення під час морфометрії даним способом проводиться візуально. Якщо ж межі досліджуваної структури нечіткі, контрастування цифрового зображення може бути використане додатково.

Крім того, розрізняється прочедура підрахунку фрагментів зображення (квадратів або пікселів), що містять фрагменти досліджуваної структури. Підрахунок квадратів за однойменного способу здійснюють вручну, оскільки ідентифікацію меж структури проводять візуально, тоді як спосіб дилатації пікселів передбачає автоматизований підрахунок за допомогою інструмента «Гістограма» програми Adobe Photoshop. 


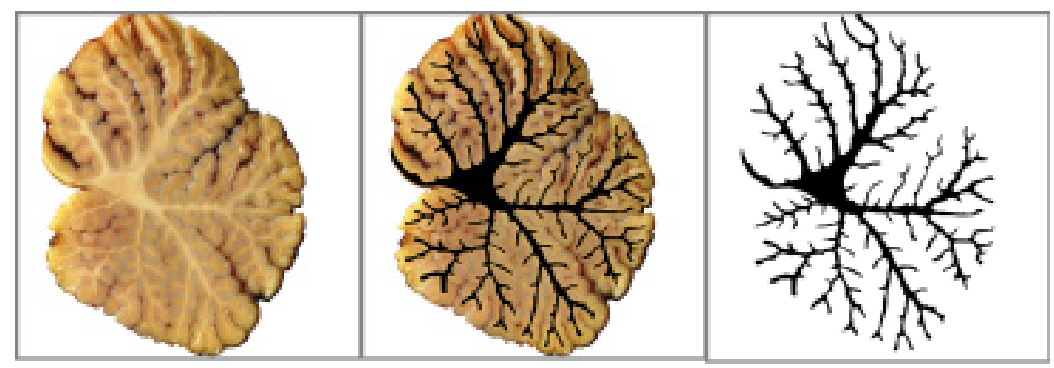

$a$

$\sigma$

B

Рис. 6. Контрастування білої речовини на макропрепараті мозочка людини

Таким чином, метод фрактального аналізу за допомогою дилатаиії пікселів має переваги перед способом підрахунку квадратів: комп'ютерне контрастування (конвертація зображення в бінарний режим) дозволяє чітко й об'єктивно визначити межі досліджуваної структури, а застосування аналітичних інструментів графічного редактора дозволяє автоматизувати дослідження (на відміну від способу підрахунку квадратів, за якого застосовують ручний підрахунок заповнених квадратів).

Відмінність способів полягає й у послідовності етапів морфометрії: від меншої кількості квадратів до більшої - при підрахунку квадратів і від більшої кількості пікселів до меншої- при підрахунку пікселів.

Спосіб дилатації пікселів є способом вибору для дослідження магнітно-резонансних томограм, рентгенограм, контрастних гістологічних мікропрепаратів та інших типів анатомічних зображень, де досліджувана структура досить контрастна (відрізняється від фону за кольором або яскравістю), рівномірно забарвлена та не має ділянок із таким самим кольором серед фонових структур.

Проте спосіб дилатації пікселів має певні обмеження в застосуванні, зумовлені низькою контрастністю цифрових зображень, коли досліджувану структуру складно автоматично відділити від фону. Якщо автоматично відділити структуру від фону неможливо, проводять ручне контрастування зображення, що є до- сить рутинною процедурою, тому для такого типу зображень доцільніше використовувати спосіб підрахунку квадратів.

Спосіб підрахунку квадратів, своєю чергою, також має певні переваги перед способом дилатації пікселів. Це - більша кількість типів зображень і структур, на яких можна обчислити фрактальний індекс. Зображення в більшості випадків не потребують попередньої обробки (контрастування й відокремлення досліджуваної структури від фону), оскільки межі структури визначаються візуально, а не автоматизовано. У зв'язку з цим спосіб підрахунку квадратів $\epsilon$ способом вибору для дослідження нативних препаратів, анатомічних макропрепаратів, гістологічних мікропрепаратів із низькою контрастністю та інших зображень, де складно або неможливо автоматизовано відділити ділянки досліджуваної структури від оточуючого фону.

\section{Висновки}

Обидві модифікації фрактального аналізу спосіб підрахунку квадратів та спосіб дилатації пікселів - дозволяють отримати практично однакові результати. Вибір способу залежить від особливостей зображення та досліджуваної структури. У випадках, якщо зображення легко автоматизовано розділити на фон і основну структуру, способом вибору є спосіб дилатації пікселів. Для більш складних структур і зображень може бути застосований спосіб підрахунку квадратів.

\section{Список літератури}

1. Степаненко А. Ю. Фрактальный анализ как метод морфометрического исследования белого вещества мозжечка человека / А. Ю. Степаненко, Н. И. Марьенко // Світ медицини та біології. 2016. - № 4 (58). - C. 127-130.

2. Mandelbrot B. B. The fractal geometry of nature / B. B. Mandelbrot. - N.Y. : W. H. Freeman\&Co, 1983. -468 c. 
3. Mandelbrot B. B. Fractals - form, chance and dimension / B. B. Mandelbrot. - San Francisco : W. H. Freeman, 1977. -365 p.

4. Фракталы и хаос в биологическом морфогенезе / [Исаева В. В., Каретин Ю. А., Чернышев А. В., Шкуратов Д. Ю.]. - Владивосток : Институт биологии моря ДВО РАН, 2004. - 128 с.

5. Fractal analysis of MR images in patients with Chiari malformation: The importance of preprocessing / E. Akar, S. Kara, H. Akdemir, A. Kiris // Biomedical Signal Processing and Control. - 2017. - № 31. P. 63-70.

6. Fractal dimension analysis of cerebellum in Chiari Malformation type I E. Akar, S. Kara, H. Akdemir, A. Kiris // Computers in Biology and Medicine. - 2015. - № 64. - P. 179-186.

7. Ristanovic D. Fractal analysis of dendrite morphology of rotated neuronal pictures: the modified box counting method / D. Ristanovic, B. D. Stefanovic, N. Puskas // Theor. Biol. Forum. - 2014. Vol. 107 (1-2). - P. 109-121.

8. Liu J. Z. Fractal dimension in human cerebellum measured by magnetic resonance imaging / J. Z. Liu, L. D. Zhang, G. H. Yue // Biophys. J. - 2003. - Vol. 85 (6). - P. 4041-4046.

9. Modified Richardson's method versus the box-counting method in neuroscience / I. Zaletel, D. Ristanovic, B. D. Stefanovic, N. Puskas // J. Neurosci. Methods. - 2015. - Vol. 242. - P. 93-96.

10. Fractal dimension analysis for quantifying cerebellar morphological change of multiple system atrophy of the cerebellar type (MSA-C) / Y. T. Wu, K. K. Shyu, C. W. Jao [et al.] // Neuroimage. - 2010. Vol. 49 (1). - P. 539-551. - DOI : 10.1016/j.neuroimage.2009.07.042.

11. Молчатский С. Л. Фрактальный анализ структуры вентромедиального ядра гипоталамуса мозга человека в пре- и постнатальном онтогенезе / С. Л. Молчатский, В. Ф. Молчатская // Новые исследования. -2010 . - № 24. - С. 60-67.

12. Степаненко А. Ю. Фрактальный анализ белого вещества мозжечка человека / А. Ю. Степаненко, Н. И. Марьенко // Світ медицини та біології. - 2017. - № 3 (61). - С. 145-149.

13. Степаненко А. Ю. Фрактальный анализ как метод морфометрического исследования поверхностной сосудистой сети мозжечка человека / А. Ю. Степаненко, Н. И. Марьенко // Медицина сьогодні і завтра. - 2015. - № 4 (69). - С. 50-55.

\section{References}

1. Stepanenko A.Yu., Maryenko N.I. (2016). Fraktalnyi analiz kak metod morfometricheskoho issledovaniia beloho veshchestva mozzhechka cheloveka [Fractal analysis as a method of morphometric study of the white matter of the cerebellum of a person]. Svit medytsyny ta biolohii - The World of Medicine and Biology, № 4 (58), pp. 127-130 [in Russian].

2. Mandelbrot B.B. (1983). The fractal geometry of nature. N.Y.: W. H. Freeman\&Co, 468 p.

3. Mandelbrot B.B. (1977). Fractals - form, chance and dimension. - San Francisco : W. H. Freeman, 365 p.

4. Isaieva V.V., Karetin Yu.A., Chernyshev A.V., Shkuratov D.Yu. (2004). Fraktaly i khaos v biolohicheskom morfoheneze [Fractals and chaos in biological morphogenesis]. Vladivostok: Institute of Marine Biology FEB RAS, 128 p. [in Russian].

5. Akar E., Kara S., Akdemir H., Kiris A. (2017). Fractal analysis of MR images in patients with Chiari malformation: The importance of preprocessing. Biomedical Signal Processing and Control, № 31, pp. 63-70.

6. Akar E., Kara S., Akdemir H., Kiris A. (2015). Fractal dimension analysis of cerebellum in Chiari Malformation type I. Computers in Biology and Medicine, № 64, pp. 179-186.

7. Ristanovic D., Stefanovic B.D., Puskas N. (2014). Fractal analysis of dendrite morphology of rotated neuronal pictures: the modified box counting method. Theor. Biol. Forum, vol. 107 (1-2), pp. $109-121$.

8. Liu J.Z., Zhang L.D., Yue G.H. (2003). Fractal dimension in human cerebellum measured by magnetic resonance imaging. Biophys. J., vol. 85 (6), pp. 4041-4046.

9. Zaletel I., Ristanovic D., Stefanovic B.D., Puskas N. (2015). Modified Richardson's method versus the box-counting method in neuroscience. J. Neurosci. Methods, vol. 242, pp. 93-96.

10. Wu Y.T., Shyu K.K., Jao C.W., Wang Z.Y., Soong B.W., Wu H.M., Wang P.S. (2010). Fractal dimension analysis for quantifying cerebellar morphological change of multiple system atrophy of the cerebellar type (MSA-C). Neuroimage, vol. 49 (1), pp. 539-551, DOI: 10.1016/j.neuroimage.2009.07.042. 
11. Molchatskii S.L., Molchatskaia V.F. (2010). Fraktalnyi analiz struktury ventromedialnoho yadra hipotalamusa mozha cheloveka $\mathrm{v}$ pre- i postnatalnom ontoheneze [Fractal analysis of the structure of the ventromedial nucleus of the human brain hypothalamus in pre- and postnatal ontogenesis]. Novyie issledovaniia - New Research, № 24, pp. 60-67 [in Russian].

12. Stepanenko A.Yu., Maryenko N.I. (2017). Fraktalnyi analiz beloho veshchestva mozzhechka cheloveka [Fractal analysis of the human cerebellar white matter]. Svit medytsyny ta biolohii - The World of Medicine and Biology, № 3 (61), pp. 145-149 [in Russian].

13. Stepanenko A.Yu., Maryenko N.I. (2015). Fraktalnyi analiz kak metod morfometricheskoho issledovaniia poverkhnostnoi sosudistoi seti mozzhechka cheloveka [Fractal analysis as a method of morphometric study of the superficial vascular network of the cerebellum of a person]. Medytsyna siohodni i zavtra - Medicine Today and Tomorrow, № 4 (69), pp. 50-55 [in Russian].

\section{Н.И. Марьенко, А.Ю. Степаненко ДВА СПОСОБА ФРАКТАЛЬНОГО АНАЛИЗА КАК МОРФОМЕТРИЧЕСКОГО МЕТОДА В АНАТОМИИ: СПОСОБ ПОДСЧЕТА КВАДРАТОВ VS СПОСОБ ДИЛАТАЦИИ ПИКСЕЛЕЙ}

Проведен сравнительный анализ двух способов фрактального анализа как метода морфометрии подсчета квадратов и дилатации пикселей. Для разработки методик фрактального анализа использовано белое вещество мозжечка человека. Проведено сравнение двух авторских модификаций методов фрактального анализа. По результатам подсчета фрактального индекса двумя различными методами на одном изображении установлено, что значения фрактального индекса, вычисленные методами подсчета квадратов и дилатации пикселей, практически не различаются. Оба метода дают сопоставимые результаты и могут быть использованы для фрактального анализа в морфометрии с одинаково высокой точностью. Выбор метода зависит от особенностей изображения и исследуемой структуры. В случаях, если изображение легко автоматически разделить на фон и основную структуру, методом выбора является метод дилатации пикселей. Для более сложных структур и изображений может быть применен рутинный метод подсчета квадратов.

Ключевые слова: морфометрия, фрактальный анализ, фрактальный индекс, подсчет квадратов, дилатация пикселей.

\section{N.I. Maryenko, O.Yu. Stepanenko TWO VARIANTS OF FRACTAL ANALYSIS AS MORPHOMETRIC METHOD IN ANATOMY: BOX COUNTING VS PIXEL DILATING TECHNIQUE}

A comparative analysis of the two methods of fractal analysis in morphometry was carried out. There are box counting method and pixel dilation method. For the development of methods of fractal analysis white matter of the human cerebellum was used. Comparison of two authorial modifications of fractal analysis methods was made. The results of the fractal dimension calculation by two different methods in one image show that the fractal dimension values calculated using the box counting method and the pixel dilation method are practically the same. Both methods are giving the comparable results and can be used for fractal analysis in morphometry with equally high accuracy. The choice of method depends on the features of the image and the structure under study. In cases where the image is easily divided automatically into the background and main structure, the pixel dilation method is the choice. The pixel dilation method is the method of choice for fractal analysis of MR images, radiographs, contrast histological microphotographs and other types of contrast and uniformly colored anatomical images with have no areas with the same color structures. For more complex structures and images, a more routine box counting method may be used. The box counting method is the method of choice for the study of microphotographs of non-stained histological slides, photographs of the inner organs, histological microphotographs with low contrast and other images with impossible automatic separation of the studied structure and surrounding background.

Keywords: morphometry, fractal analysis, fractal dimension, box counting, pixel dilation.

Надійшла 09.04.19 


\section{Відомості про авторів}

Мар'єнко Наталія Іванівна - кандидат медичних наук, асистент кафедри гістології, цитології та ембріології Харківського національного медичного університету.

Адреса: 61022, м. Харків, пр. Науки, 4, Харківський національний медичний університет. Тел.: +38(095)140-50-88.

E-mail: maryenko.n@gmail.com.

ORCID: https://orcid.org/0000-0002-7980-7039.

Степаненко Олександр Юрійович - доктор медичних наук, доцент, завідувач кафедри гістології, цитології та ембріології Харківського національного медичного університету.

Адреса: 61022, м. Харків, пр. Науки, 4, Харківський національний медичний університет.

Тел.: +38(067)377-18-44.

E-mail: stepanenko@3g.ua.

ORCID: https://orcid.org/0000-0002-5686-0857. 